\title{
Research on Entrepreneurship Education Development in Japanese Universities — Taking Sojo University as an Example
}

\author{
Huan Wang, Shuang Geng, and Xi Song
}

\begin{abstract}
Since entrepreneurial education in China is still in the exploratory stage, it is instructive to examine the successful mode of entrepreneurial education in foreign universities, and constantly improve the entrepreneurial education system of Chinese universities. Japan as a great counterpart in Asian higher education, has attached great importance to the implementation of entrepreneurial education and continuous, innovation in the mode of it, and formed own characteristics in terms of entrepreneurial education. This paper analyzes entrepreneurial courses, entrepreneurial teams and entrepreneurial support of Japanese universities. The finding can provide reference for Chinese entrepreneurial education and is expected to promote development of the entrepreneurial education. At present, the field of domestic entrepreneurial education is underdeveloped in China. This paper, through the case analysis of Japanese entrepreneurial education, will fulfill the knowledge gap and facilitate the study of Chinese entrepreneurial education.
\end{abstract}

Index Terms-Japanese entrepreneurial education, entrepreneurial course, entrepreneurial team, entrepreneurial support.

\section{INTRODUCTION}

Entrepreneurial education in Chinese universities starts late and is still in the stage of exploration, which obviously drops behind the actual needs of contemporary higher education. Historically, Japan began to develop entrepreneurial education for college students since 1990s. In past 20 years, under the social support system closely coordinated by the government, industry and university. Japan has gradually formed a systematic and localized entrepreneurial education mode. Since Japan and China have similar culture and education tradition, the success in the entrepreneurial education mode in Japanese universities will undoubtedly be a significant reference for the entrepreneurial education development in Chinese universities.

Manuscript received January 9, 2019; revised July 1, 2019. This work was supported in part by Project of Innovation and Entrepreneurship Education Research Centre for University Student of Guangdong Province (2018A073825), Research Cultivating Project of Shenzhen Institute \& Information Technology (ZY201717), and Natural Science Foundation of Guangdong Province (2016A030310074).

Huan Wang is with the Greater Bay Area International Institute for Innovation, Shenzhen University, Shenzhen, China (e-mail: huanwang2020@163.com).

Shuang Geng is with the College of Management, Shenzhen University, Shenzhen, China, and Greater Bay Area International Institute for Innovation, Shenzhen University, Shenzhen, China (e-mail: gracegeng0303@163.com).

$\mathrm{Xi}$ Song is with the Greater Bay Area International Institute for Innovation, and School of Entrepreneurship, Shenzhen University, Shenzhen, China (e-mail: sissie.song@gmail.com).
In this paper, entrepreneurial education of Sojo University is taken as an example. Through the analysis of entrepreneurial courses, entrepreneurial teams and entrepreneurial support in Japanese universities, Chinese universities could benefit from their experience, thus improving the implementation approach of entrepreneurial education.

\section{THEORETICAL FOUNDATION}

\section{A. Concept of Japanese Entrepreneurial Education}

Entrepreneurial education is divided into broad and narrow entrepreneurial education [1]. In a narrow sense, entrepreneurial education is defined as the education for entrepreneurs. In a broad sense, entrepreneurial education refers to the cultivation of entrepreneurship [1]. Entrepreneurial talents are defined as those who are not afraid of challenges and capable to challenge new things and practices boldly [2]. Current entrepreneurship education in Japanese universities, taking the broad entrepreneurial education as the core, mainly cultivates entrepreneurship. Japanese entrepreneurial education includes entrepreneurship (challenge spirit, etc.), entrepreneurial ability (imagination and creativity, etc.), entrepreneurial skills (structure and ideas of economic activities, etc.) [3].

\section{B. Features of Japanese Entrepreneurial Education}

\section{1) Systematization of entrepreneurship education}

Japanese entrepreneurship education system has been formed from primary school to university. At different stages, students accept different contents and forms of entrepreneurship education.

In Japan, primary school is the "cradle stage" of entrepreneurship education, while such stage focuses on the cultivation of students' entrepreneurship [4]. It includes the education of Corporate Social Responsibility. In elementary school, it is necessary for children to understand the importance of doing work that is needed by others.

In the middle school stage, education with regards to business management method is introduced. The contents include the assessment of business (what products will sell well under given conditions), the business plan for generating profits, the necessity of adjusting prices and sales volume, etc. [5], [6]. However, some education content is not represented here. For example, linking your strengths to your career, teamwork, work environment, etc., are not mentioned.

Universities play a key role in entrepreneurship education. 
Based on the initiatives of entrepreneurship education, universities further strengthen the education on business management method. At the same time, the education of entrepreneurial knowledge and skills is carried out [7].

As mentioned above, Japanese schools adopt different forms of entrepreneurship education courses from primary school to university so as to cultivate students' entrepreneurship knowledge and skills.

\section{2) Diversity of entrepreneurship education}

Japanese universities have different training objectives and courses for entrepreneurship education. According to different conditions of the school and location, different types of entrepreneurial talent training objectives are proposed.

TABLE I: DIVERSITY OF ENTREPRENEURSHIP EDUCATION

\begin{tabular}{|c|c|c|}
\hline Type & Definition & Case \\
\hline $\begin{array}{l}\text { Specialized } \\
\text { entrepreneurship } \\
\text { education }\end{array}$ & $\begin{array}{l}\text { Specialized curriculum for } \\
\text { students of school of } \\
\text { economics/business who are } \\
\text { actual entrepreneurs or } \\
\text { aspiring for entrepreneurship }\end{array}$ & $\begin{array}{l}\text { Tokyo University } \\
\text { of Technology }\end{array}$ \\
\hline $\begin{array}{l}\text { Integrated } \\
\text { management skill } \\
\text { education }\end{array}$ & $\begin{array}{l}\text { Developing business plan to } \\
\text { the school of economics or } \\
\text { business school }\end{array}$ & Keio University \\
\hline $\begin{array}{l}\text { Sub-specialized } \\
\text { entrepreneurship } \\
\text { education }\end{array}$ & $\begin{array}{l}\text { Curriculum for students } \\
\text { majoring in engineering and } \\
\text { medicine and taking } \\
\text { entrepreneurship as } \\
\text { subspecialty }\end{array}$ & $\begin{array}{l}\text { Kwansei Gakuin } \\
\text { University }\end{array}$ \\
\hline $\begin{array}{l}\text { Spiritual } \\
\text { entrepreneurhip } \\
\text { education }\end{array}$ & $\begin{array}{l}\text { Curriculum of } \\
\text { entrepreneurship for all } \\
\text { students }\end{array}$ & $\begin{array}{l}\text { Yokohama } \\
\text { National } \\
\text { University }\end{array}$ \\
\hline
\end{tabular}

Source: Ministry of economy, trade and industry, (2010) university entrepreneurship education report (R), 2009,12.

Table I shows that four main types of entrepreneurship education in Japan. The first category is Specialized entrepreneurship education, under which students are ambitious and aspired to start a real business. Tokyo University of Technology is the typical example university that promotes entrepreneurship major, which is based on the high-tech of computer science, biology, media science and medical science, aims to create new market value and cultivate entrepreneurs, and to open up basic courses for students (management, economics, finance, etc.) and specialized course (enrepreneruship planning theory, accounting, marketing, etc.). Therefore, students majoring in entrepreurship courses are able to combine technological and entrepreneurial knowledge. After graduation, they are expecte to set up venture companies or start new business within enterprises [8].

The second type is Integrated management skill education, which enables students comprehensively exercising management skills. The business school of Keio University is a representative example, with regional entrepreneurer cultivation programs. It introduces social elites who own rich work experience to systematically explain essential entrepreneurial abilities for students about regional entrepreneurship [9].

The third type is the Sub-specialized entrepreneurship education, which is developed for students majoring in engineering, medicine and so on, and taking entrepreneurship as subspecialty. The representative example is the social entrepreneurship major of Kansai University, which is through classroom teaching and practical courses, to cultivate social entrepreneurs to contribute to regional and international communities. Moreover, by cooperating with domestic and foreign NPO, NGO, welfare institutions, enterprises and administrative institutions, this major has established a practical education research system that rapidly responds to modern social problems through internships and overseas field trips [10].

The fourth type is Spiritual entrepreneurship education, which targets at all students. A typical case is the entrepreneurship education project of Yokohama National University, in which students implement business and career education plannings. In addition, when students' creative plans are adopted by external enterprises, the project will build up mechanisms to support students' entrepreneurship including financial assistance [11].

\section{Industry-University-Government Cooperation}

The Japanese government attaches great importance to industrialize the research outputs of the schools in order to promote innovation in the economic field. University entrepreneurship is perceived as an effective channel to industrialize research outputs. Driven by that, Japanese government is determined to promote entrepreneurship education by promoting the cooperation between government, enterprises and schools [12].

At the government level, in order to solve the problems of insufficient entrepreneurial talents and capital, the Japanese government has issued a series of policies to support entrepreneurship education, providing a good environment for entrepreneurship education courses in universities [13].

In terms of industry, education courses of entrepreneurship in Japanese universities will be created from the perspective of revitalizing regional economy by combining the specialties with regional characteristics, such as paper entrepreneurship and business street entrepreneurship. Apart from that, the active collaboration between school and enterprises generates, considerate supports for the cultivation of entrepreneurial talents and the training of practical talents [14].

\section{CASE STUdY}

In the development of Japanese entrepreneurship education, universities have played an important role in cultivating diverse entrepreneurial talents. Universities will comprehensively consider the location, development level and favorable conditions of the school, and put forward different types of training objectives for entrepreneurial talents. In facing with regional brain drain, Sojo University has been cultivating entrepreneurial talents to promote the development of local industries. In this paper, the entrepreneurial education mode of Sojo University will be studied and analyzed from three aspects as entrepreneurship courses, entrepreneurship teams and entrepreneurship support. 


\section{A. Entrepreneurship Courses}

\section{1) Pre-entrepreneurship course}

In addition to the basic knowledge of management such as project planning, financing, financial statements, etc., the early-stage entrepreneurship courses also involve new entrepreneurial knowledge fields, including the Internet of Things, artificial intelligence, financial technology, etc., combined with the changes of times as shown in Table II . Sojo University has established a complete and systematic entrepreneurship theory and developed its own professional entrepreneurship teachers.

TABLE II: PRE-entrepreneurship of Sojo University

\begin{tabular}{|c|c|}
\hline Course & Content \\
\hline Entrepreneurial spirit & Case analysis of entrepreneurs, \\
\hline Business model & Microsoft, apple, Google \\
\hline Internet of Things & $\begin{array}{l}\text { IoT learning and group } \\
\text { discussion }\end{array}$ \\
\hline $\begin{array}{l}\text { Industry } 4.0 \text { (fourth industrial } \\
\text { revolution) }\end{array}$ & 21 st century manufacturing \\
\hline Big data and artificial intelligence & $\begin{array}{l}\text { Deep learning and the new } \\
\text { business of AI }\end{array}$ \\
\hline Shared economic & Sharing economy structure \\
\hline FinTech & Fintech business \\
\hline $\begin{array}{l}\text { The necessary conditions for starting } \\
\text { business }\end{array}$ & $\begin{array}{l}\text { How do young people start } \\
\text { business }\end{array}$ \\
\hline Business planning and capital policy & Business plan and financing \\
\hline Entrepreneurial environment & $\begin{array}{l}\text { Silicon valley's innovation } \\
\text { ecosystem }\end{array}$ \\
\hline
\end{tabular}

Source: Entrepreneurship project in the homepage of Sojo University, http://www.sojo-v.com/school.

\section{2) Post-entrepreneurship course}

In the later courses as shown in Table III, students are divided into groups, and work out business plans through group cooperation, and finally participate in the business competition of Sojo University. It can be acquired that entrepreneurial courses in Japan both competitive at theoretical knowledge, and practical application.

TABLE III: POST-ENTREPRENEURSHIP OF SOJO UNIVERSITY

\begin{tabular}{ll}
\hline \hline Course & Content \\
\hline Business proposal & Business model analysis, design \\
& methods, business model \\
& production \\
Commercial competition & $\begin{array}{l}\text { Business competitions jointly } \\
\text { organized by Sojo University and } \\
\text { other organizations }\end{array}$ \\
\hline \hline
\end{tabular}

Source: Entrepreneurship project in the homepage of Sojo University, http://www.sojo-v.com/school.

\section{B. Entrepreneurship Team}

On October 2014, the entrepreneurship department of Sojo University was established. It is the first recognized undergraduate entrepreneurship club activity in Japan, aiming to cultivate entrepreneurial talents. Besides, the entrepreneurship department develops business plans and participates in business competitions at home and abroad. Sojo University has made great achievements in cultivating entrepreneurial talents. The following introduces the team developing Hero Leg and analyzes the characteristics of the entrepreneurial team of Japanese student.

The team consists of five students from the College of Art, the Department of Informatics, the School of Biological Life, and the Department of Medicine. Students from the College of Art are in charge of design while students of the Department of Informatics are responsible for programming. Students of the School of Biological Life undertake project management. Students majoring in Medicine utilise their advantaged proficiency in English to lead overseas development. Therefore, a same entrepreneurial team is made up by students from different majors using their own strengths to promote the project.

In addition, they also developed Hero Leg together with the high-tech enterprises in Kumamoto county. Entrepreneurial teams from Japanese universities will actively cooperate with related enterprises, which not only fully utilise off-campus resources, but also make entrepreneurial projects closer to the actual needs of the society.

\section{Entrepreneurship Support}

In entrepreneurship education, Sojo university also acts as a guide and support for students' entrepreneurship projects. The necessary support provided by the school is "Place", "Fund" and "Consultant".

\section{1) Place support}

In 2014, the activity space of the entrepreneurship department, is a research room that can only accommodate 10 members. In 2016, it is expanded to $400 \mathrm{~m}^{2}$ facilities exclusively for entrepreneurship. The establishment of a fixed place for starting a business is conducive to the exchange of entrepreneurship among students and the long-term development of entrepreneurial projects.

\section{2) Funding support}

Student entrepreneurship also needs venture capital, such as funds for trial product development and entry fees of business plan. Providing the required trial development costs in the form of ideas can encourage students to take a big step in entrepreneurship. In the national business plan competition, the presence or absence of a trial product is a measure of "likelihood of success". In addition, venture capital financing also matters.

\section{3) Consultant support}

There are networks with venture entrepreneurs in Tokyo for student entrepreneurship support, where entrepreneurship experts serve as consultants. Japanese universities offer practical education and support to students by utilizing experienced external entrepreneurship experts.

\section{INSPIRATION FROM JAPANESE ENTREPRENEURSHIP EDUCATION}

\section{A. Entrepreneurship Courses}

Entrepreneurship education in Japan has formed a coherent curriculum system from primary school to university. In different stages of education, different forms and levels of entrepreneurship education are carried out for students 
accordingly.

In addition, Japanese universities have created a curriculum system with school characteristics and proposed corresponding training objectives for entrepreneurial talents according to school conditions. Similarly, Chinese universities could diversify entrepreneurship talent training plan according to different advantages of them or local characteristics.

\section{B. Entrepreneur Team}

Entrepreneurship teams at Japanese universities advocate entrepreneurship among students of different majors. The school holds entrepreneurship exchange activities for students of different majors to promote their joint entrepreneurship and flexible use of their professional fields. In addition, the entrepreneurial team of Japanese universities focuses on cooperation with enterprises. The Japanese entrepreneurial team has in-depth cooperation with relevant enterprises, making full use of technology, capital and other resources. Joint development of entrepreneurial projects with enterprises is conducive to entrepreneurial products and services closer to the actual needs of society.

\section{Entrepreneurship Support}

\section{1) Place support}

In order to promote entrepreneurship exchanges and the long-term development of entrepreneurship programs, Japanese universities have been expanding their entrepreneurship bases to provide students with a fixed place to start a business, and almost all of them are provided free of charge. This is the biggest platform guarantee for students in the initial stage of entrepreneurship.

\section{2) Funding support}

Capital is a realistic problem in the process of innovation and entrepreneurship .Japanese universities and the government provide a large amount of special funds for start-ups to support students' innovation and entrepreneurship, including product trial production, business planning competition and other activities, to encourage students to start their own businesses. At the same time, colleges and universities should strengthen the introduction of outside investment funds to minimize the financial concerns of college entrepreneurs.

\section{3) Cooperation between government, industry and universities}

Japanese universities pay attention to the cooperation with enterprises and the government. In order to solve the problem of insufficient entrepreneurial talents and capital, the Japanese government has issued a series of policies to support entrepreneurship education. To cultivate practical entrepreneurial talents, enterprises are actively engaged to give great support, and nurturing a good external environment for entrepreneurship education.

\section{CONCLUSION}

To conclude, Japanese universities have diverse training objectives and courses of entrepreneurship education. In terms of the target positioning in entrepreneurship education, the training objectives will be proposed based on conditions of each school and the location. To deal with the problems of regional brain drain, Sojo University, a typical entrepreneurial university in Japan, has been cultivating entrepreneurial talents to promote the development of local industries, and ultimately formed its own characteristics in curriculum setting, entrepreneurial teams and support system. Japanese entrepreneurship education of the case university can be used for the reference to improve the education of China in the field of innovation and entrepreneurship. Firstly, Chinese universities can build the training objectives and courses of entrepreneurial education on the basis of their advantages or local characteristics. Secondly, entrepreneurial teams of university students can be integrated with wider resources by cooperating with enterprises. Lastly, close coordination of government, industry and university on entrepreneurial education can integrate most resources and optimize supports for students. In addition, theoretical research related to entrepreneurial education in China, is still in the stage of scarcity. By analyzing Japanese entrepreneurial education can promote the research on the combination of entrepreneurship practice and theory.

\section{CONFLICT OF INTEREST}

The authors declare no conflict of interest.

\section{AUTHOR CONTRIBUTIONS}

Huan Wang wrote the paper; Xi Song and Shuang Geng revised the paper; Shuang Geng was responsible for meeting registration and email contact. All authors had approved the final version.

\section{ACKNOWLEDGMENT}

The work described in this paper was supported by Project of Innovation and Entrepreneurship Education Research Centre for University Student of Guangdong Province (2018A073825), Research Cultivating Project of Shenzhen Institute \& Information Technology (ZY201717), and Natural Science Foundation of Guangdong Province (2016A030310074).

\section{REFERENCES}

[1] T. Azim, "Entrepreneurship education and training," Education and Training, vol. 47, pp. 158-169, 2010

[2] OECD, "Entrepreneurial talent," Measuring Innovation, vol. 14, pp. 54-55, 2010

[3] L. Shi and A. Yonezawa, "Innovation and entrepreneurship: Trials of Japanese universities," Globalization Societies and Education, vol. 10, no. 3, pp. 367-385, 2012.

[4] E. Yamane, "Entrepreneurship education in the 'period for integrated study' in elementary and lower secondary schools in Japan," Social and Economic Education, vol. 5, no. 1, pp. 44-52, 2002.

[5] U. Hiroko, "Entrepreneurship education in elementary and secondary schools of Japan," UNIDO Conference on Fostering Entrepreneurial Youth, pp. 1-11, November 2014.

[6] J. Oheki, "The entrepreneurship education in university in Japan: The Ways of Entrepreneurship Education Based on the Quantitative Analysis," Business Creator Research, vol. 7, pp. 1-19, 2016.

[7] T. Shinato, K. Kamei, and L. P. Dana, "Entrepreneurship education in Japanese universities - How do we train for risk taking in a culture of risk adverseness," International Journal of Entrepreneurship and Small Business, vol. 20, no. 2, pp. 184-204, January 2013. 
[8] (2019). Entrepreneurship project in the homepage of Tokyo University of Technology. [Online]. Available: https://www.teu.ac.jp/grad/ep/index.html

[9] (2019). Homepage of business school in Keio University. [Online] Available: http://www.kbs.keio.ac.jp/mb/101.html

[10] (2019). Homepage of social entrepreneurship in Kwansei Gakuin University. [Online]

Available: https://www.kwansei.ac.jp/s_hws/s_hws_000109.html

[11] (2019). Homepage of entrepreneurship education program in Yokohama National University. [Online]. Available: https://www.cba.ynu.ac.jp/career/education/keiei/

[12] L. Liao, Y. L. Ting, and L. Huang, "The status of the entrepreneurship education in Japan," Economics and Management, vol. 1, pp. 269-273, 2013.

[13] M. Ono, "Historical aspects and current status of entrepreneurship in Japanese universities," Japanese Business Administration, vol. 8, no. 1, pp. 1-16, 2012

[14] B. Allan and M. Hitoshi, "Entrepreneurs and entrepreneurial processes: Historical and theoretical perspectives on entrepreneurship in the Japanese contexts," Asian Perspective, vol. 27, no. 3, pp. 125-175, 2003.

Copyright $\odot 2019$ by the authors. This is an open access article distributed under the Creative Commons Attribution License which permits unrestricted use, distribution, and reproduction in any medium, provided the original work is properly cited (CC BY 4.0).

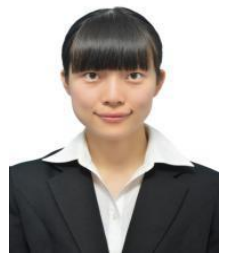

Huan Wang was born on February 4, in 1990 in Jiangsu province. She studied in Meiji University in Japan from Apr. 2016 to Mar. 2018 and was granted master's degree in Meiji University on Mar. $26^{\text {th }}$ in 2018. Her main research field is in social enterprises and social investment. She currently works as research assistant in School of Entrepreneurship of Shenzhen University.

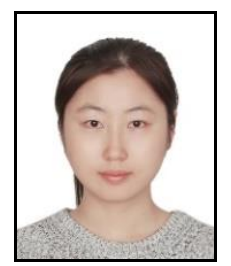

Shuang Geng received the B.S. degree in engineering from City University of Hong Kong, Hong Kong SAR, P.R. China, in 2013 and the Ph.D. degree from City University of Hong Kong in 2017. She is research associate at Colledge of Management, Shenzhen University. Her research interests include innovation and entrepreneurship management, project management, knowledge discovery, and recommender system. Her papers appear in Project Management Journal, International Journal of Technology and Design Education, etc.

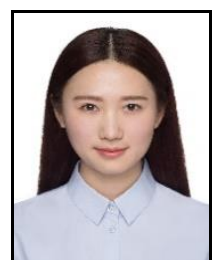

Xi Song is now working as research assistant in the School of Entrepreneurship of Shenzhen University. She obtained the master degree in human resource management in the University of Birmingham in the United Kingdom from Sep. 2015 to Dec. 2016 and was awarded dual bachelor degree from Vaasa University of Applied Science in Finland and Hubei University of Technology in China from Sep. 2011 to Jun. 2015. Her main research field is HRM and entrepreneurship. 